\title{
New Middle Cambrian lingulate brachiopods from the Skryje-Týřovice area (Central Bohemia, Czech Republic)
}

\author{
MiCHAL MERGL \& VRATISLAV KORDULE
}

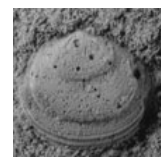

\begin{abstract}
A new lingulate brachiopod assemblage has been found in the early Middle Cambrian Týrovice Greywackes of the Skryje-Týřovice area (Central Bohemia, Czech Republic). A new species, Lingulella agaue sp. n., a minute indeterminable lingulid, a ceratretid Almohadella braunae Streng, 1999, and an acrotretid Treptotreta? sp. have been ascertained in the fauna. Four species in one bed is the most diverse lingulate fauna in the area. Associated faunas indicate a shallow marine nearshore environment with a simple trophic structure dominated by an eoorthid Pompeckium kuthani (Pompeckj, 1896), and a few other epibenthic low suspension feeders, as well as uncommon scavengers and browsers. The presence of Almohadella braunae Streng, 1999 is the first incidence of a ceratretid within territory of the Perunica terrane. - Key words: Brachiopoda, Lingulata, Ceratretida, taxonomy, palaeoecology, Middle Cambrian, SkryjeTýřovice area, Czech Republic
\end{abstract}

Mergl, M. \& Kordule, V. 2008. New Middle Cambrian lingulate brachiopods from the Skryje-Týřovice area (Central Bohemia, Czech Republic). Bulletin of Geosciences 83(1), 11-22 (10 figures). Czech Geological Survey, Prague. ISSN 1214-1119. Manuscript received November 28, 2007; accepted in revised form January 17, 2008; issued March 31, 2008.

Michal Mergl, Department of Biology, Faculty of Education, University of West Bohemia in Plzeň, Klatovská 51,30619 Plzeň, Czech Republic; mmergl@kbi.zcu.cz•Vratislav Kordule, Dlouhá 104, 26101 Př́bram III, Czech Republic

In Central Bohemia of the Czech Republic, Middle Cambrian marine deposits with macrofossils including lingulate brachiopods are known in two areas: the Př́ibram-Jince Basin and the less extensive Skryje-Týřovice area.

In the Příbram-Jince Basin, the lingulate brachiopods are the dominant fossils near the base (OrnamentaspisConocoryphe horizon), and they occur recurrently in the summit of the Jince Formation (Rejkocephalus-Lingulella Subzone) (Fatka et al. 2004). Their composition, spatial and stratigraphical distributions confirm that the original inshore benthic associations were of very low diversity with a predominance of lingulides and possibly also other soft-bodied infaunal macroinvertebrates (evidenced by trace fossils) over other shelly fauna. The associated shelly fauna is rare and represented by ellipsocephalid and paradoxidid trilobites, and bradoriid arthropods (Šnajdr 1975, Fatka et al. 2004). Similar low-diversity lingulid associations are common in the mid to late Cambrian and lower Ordovician successions worldwide. They have been described variously as "Lingula Communities", "Lingula Flags", "Dalle à Lingules" and "Obolus beds" in most palaeocontinents, irrespective of palaeoclimate (e.g., Biernat \& Tomczykova 1968; Legrand 1973, 1985; Havlíček 1989; Popov et al. 1989; Ushatinskaya 1996; Bassett et al. 2002). The associations usually consist of highly endemic taxa. These flourished on siliciclastic substrates in stressed inshore environments in habitats similar to those of their extant relatives (Emig 1999).
In the Skryje-Týřovice area, the second significant area with Middle Cambrian marine sediments in Central Bohemia, lingulate brachiopods are rare. Until recently, only small numbers have been reported from deeper offshore biofacies (Mergl \& Šlehoferová 1990). These dwarf lingulids are a subsidiary component in predominantly trilobite assemblages. Inshore lithofacies near the base of the Middle Cambrian succession are characterized by eoorthids and protorthids, namely Pompeckium kuthani (Pompeckj, 1896), Jamesella perpasta (Pompeckj, 1896), and J. subquadrata (Pompeckj, 1896). Trilobites and helcionellid molluscs are less common. To the present time, only three shells of a large lingulid have been found in the Týrovice Greywackes at Lohovice (Mergl \& Šlehoferová 1990; p. 77, pl. 3, figs 5-8).

The new locality in the Týrovice Greywacke, observed by one of the author (VK) in a gorge near Čilá west of Skryje (Figs 1,2) yielded a surprisingly diverse fauna of shoreface origin. Apart of the typically dominant Pompeckium kuthani, a remarkably diverse association of lingulate brachiopods, trilobites, and molluscs has been observed. Two lingulids and two acrotretoids including a ceratretid Almohadella braunae Streng, 1999 have been ascertained. The last species was originally described from the early Middle Cambrian of Morocco; it is the first report of a ceratretid in the early Palaeozoic of central Europe and the Perunica terrane. 


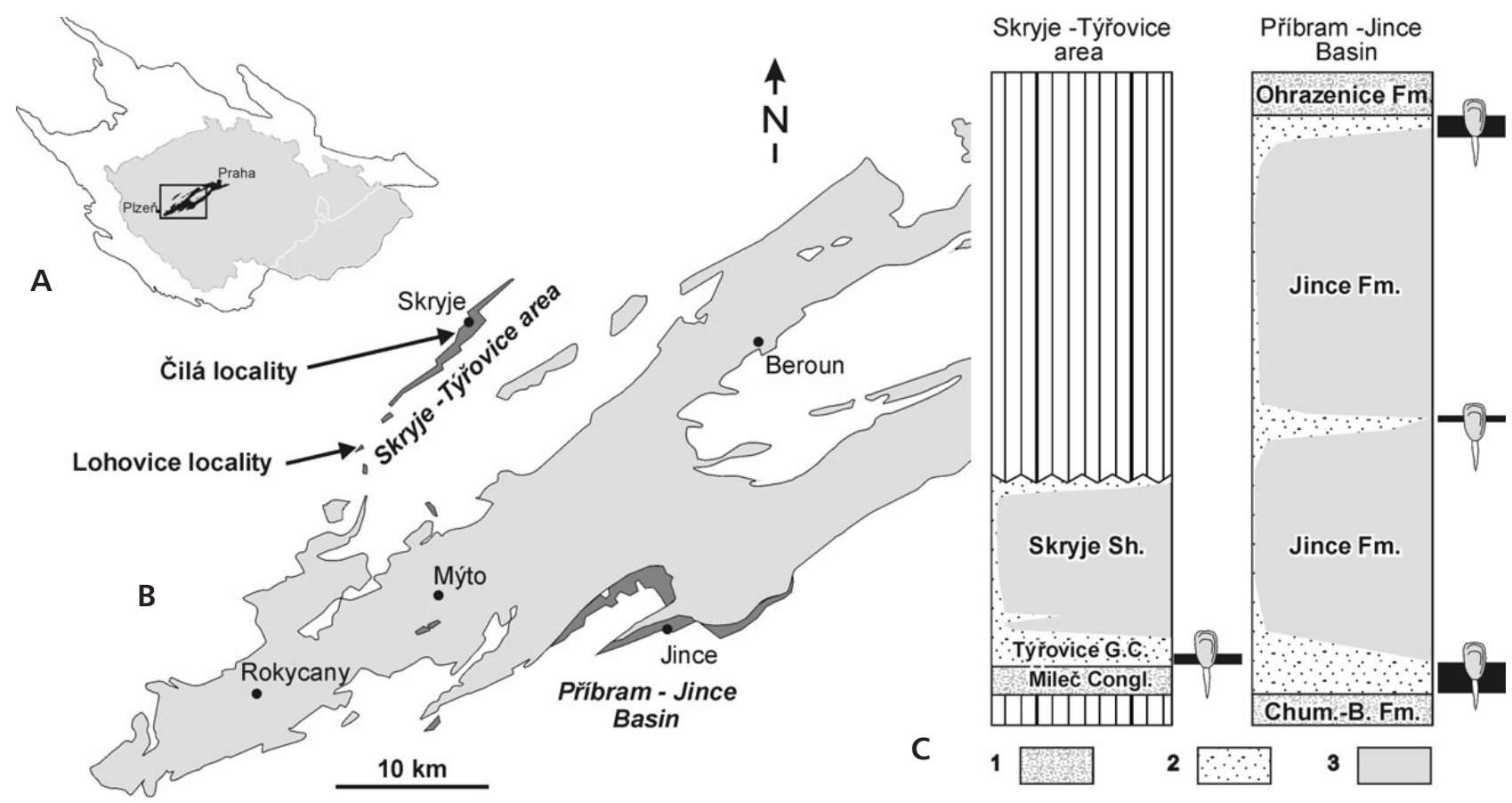

Figure 1. A - map of the Bohemian Massif showing the Czech Republic and Cambrian and Ordovician rocky. $\bullet$ B - Cambrian (dark grey) and Ordovician (pale grey); arrows indicate Čilá and Lohovice localities. $\bullet \mathrm{C}$ - simplified lithostratigraphy of the Middle Cambrian in the Skryje-Týřovice area and the Př́ibram-Jince Basin with marked horizons of lingulid associations. 1 - conglomerate and gravelstone, 2 - sandstone, 3 - siltstone and shale. Abbreviations: Chum.-B. - Chumava-Baština, G.C. - Greywackes and Conglomerates, Fm. - Formation, Sh. - Shales.

\section{Material and methods}

Shells of lingulate brachiopods are preserved as internal and external moulds in weathered and decalcified greywacke. The original shell material has been naturally removed and its remains are preserved as white soft material covering the moulds. A careful removal of the shell remains from internal and external moulds using hydrochloric acid resulted in almost featureless moulds. Therefore, fine details and structures of the shell-wall are obscured.

The siliciclastic matrix does not allow chemical release of shells from the rock, a standard method used in carbonate rocks. Because many microscopic details could not be observed, the systematic positions of two species remain unclear. Despite this unsufficiency, all species are described and illustrated because of the unique nature and outstanding environmental and palaeogeographical significance of the fauna.

Measurements (in $\mathrm{mm}$ ) have been made as follows: $\mathrm{L}-$ sagittal length, W - maximum width, $\mathrm{H}$ - maximum height, VV - ventral valve, DV - dorsal valve, $\mathrm{n}$ - number of specimens.

All specimens are deposited in the palaeontological collection of the Department of Biology, University of West Bohemia in Plzeň (PCZCU 1675-1679, 1682-1713).

\section{Lithology and taphonomy}

Shells have been collected from a weathered, originally highly calcareous greywacke interbed (Týřovice Greywacke) in a siltstone and claystone succession (Skryje Shales; Fig. 3). The interbed is slightly lenticular in section, with the maximum thickness of almost $12 \mathrm{~cm}$ in its thickest central part. In an exposed part, the bed wedges out toward $\mathrm{W}$ and $\mathrm{E}$ to less than $5 \mathrm{~cm}$. The estimated diameter of the bed is $5-7 \mathrm{~m}$.

The base is sharp, resting on an unfossiliferous fine grey siltstone. The lower part of the bed is characterized by scattered, 5 to $15 \mathrm{~mm}$-sized, angular, subangular and rounded pebbles of grey chert and white quartz mixed with coarse sand grains and bioclasts. The layer with pebbles grades upward to fine sand with abundant, chaotically spaced, often packed and tightly nested shells of Pompeckium kuthani, rare acrotretids, and other less abundant fossils (Fig. 3). The shell accumulation is followed by a fine-grained sorted sandstone without distinct bedding with scattered shells of Pompeckium kuthani, which continues upward to fine sandstone with distinct lamination and a layer with shells. This last layer also contains shells of Pompeckium kuthani, as well as valves and fragments of Lingulella agaue, and abundant acrotretids. Shells in this layer are mostly oriented parallel with bedding, both in convex-up or convex-down orientation. Moderate com- 
pression without breakage of shells is common. A thin clayey layer with a sharp base forming the summit of the bed is already unfossiliferous. This general vertical fabric of the bed undergoes to some lateral changes. Prominent shell accumulation in the lower part of the bed locally wedges out or forms nests surrounded by greywacke with few fossils. There are no trace fossils in the bed.

Another similar bed of carbonate greywacke with rare fossils has been observed below the bed. All beds form intercalations in 4 metres thick lithologically uniform succession of siltstones and claystones, outcropping above 7 metres thick poorly fossiliferous massive greywackes (Fig. 3).

The lithology of the fossiliferous beds indicates that they represent material of shoreface origin deposited below a fairweather wave-base in a moderately deep environment. For stratigraphy, lithology and palaeontological content of the Týrovice Greywackes and Conglomerates see Havlíček (1970, 1971), Kukal (1971), Šnajdr (1958), and Kordule (2006).

\section{Taxonomic composition of the taphocoenose}

Lingulate brachiopods are moderately common fossils in the greywacke intercalation, representing less than $5 \%$ of all preserved shelly fauna. Shells of the eoorthid Pompeckium kuthani dominate by more that $90 \%$ of the preserved shelly fauna. Shells of Lingulella agaue sp. n. and isolated and mostly fragmental parts of trilobite exoskeletons are less frequent, representing together $\mathrm{ca} 2-5 \%$. In decreasing significance, the trilobites are represented by Lobocephalina emmrichi (Barrande, 1846), Germaropyge germari (Barrande, 1852), Ptychoparia striata (Emmrich, 1839), Ptychoparioides torifrons (Pompeckj, 1896) and already very rare Agraulopsis roesseri Růžička, 1939. A ceratretid Almohadella braunae represents less than 1\% and remaining lingulate brachiopods are very rare. Molluscs are very rare (less than $0.5 \%$ ) being represented by a few specimens among several hundreds of collected shells. Shells of Pelagiella sp., Helcionella sp. and cup-like shells of unclear affinity have been ascertained. Apart from these taxa, wrinkled calcareous tubes of unknown affinity and a single phosphatic sclerite similar to the problematic Supinella Kraft \& Kraft, 1992 have been ascertained.

\section{Autecology and trophic structure}

It is evident that the shelly fossils in the bed represent displaced material of a shallow-water, shoreface origin. The autecology of all preserved groups, including feeding habit and trophic structure of the original community can be reliably deduced (Fig. 4).

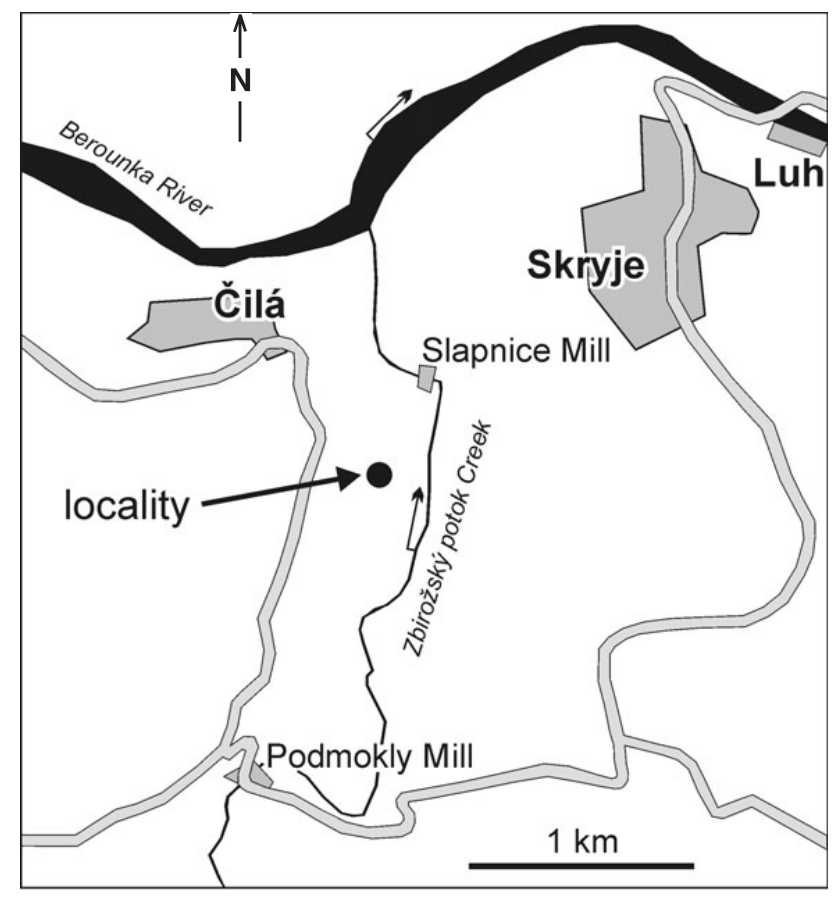

Figure 2. Map of the Skryje-Týřrovice area with marked site of a gorge near Čilá.

The eoorthid Pompeckium kuthani was an epibenthic species living apparently in a high-energy shoreface regime. It is thick-walled and a shell strengthened by prominent ribs with a strongly convex ventral valve and a prominent ventral interarea having a large pedicle opening. An individual was bonded by the pedicle to gravel or sand grains. Shells of this species are known from fine to coarse sandstones and also in gravelstones. A high abundance of shells indicates that the species was a dominant low epifaunal suspension feeder in shallow nearshore waters on a bottom of sand and fine gravel.

Unlike Pompeckium kuthani, the lingulid Lingulella aguae was a shallow semi-infaunal burrower living on fine sands and clayey sands. The elongate, moderately thick, smooth and rather convex shell was in life slightly buried by the apex in the fine sand and firmly anchored by the long cylindrical pedicle. Associated but rare small lingulates with a parallel-sided shell (gen. et sp. indet.) should be probably a deeper infaunal burrower with long pedicle living in the same substrate, but direct evidence is missing.

A cup-like ceratretid Almohadella braunae likely was an epibenthic or very shallow semi-infaunal species with the dorsal valve having an opercular function. The pedicle was anchored by the distal part to large sand grains or small bioclasts. Ceratretids differ significantly from other acrotretoids by a slit-like external pedicle opening. In other families of the Acrotretoidea (Acrotretidae, Scaphelasmatidae, Torynelasmidae, Ephippelasmatidae, Biernatidae), the pedicle foramen is circular or subcir- 


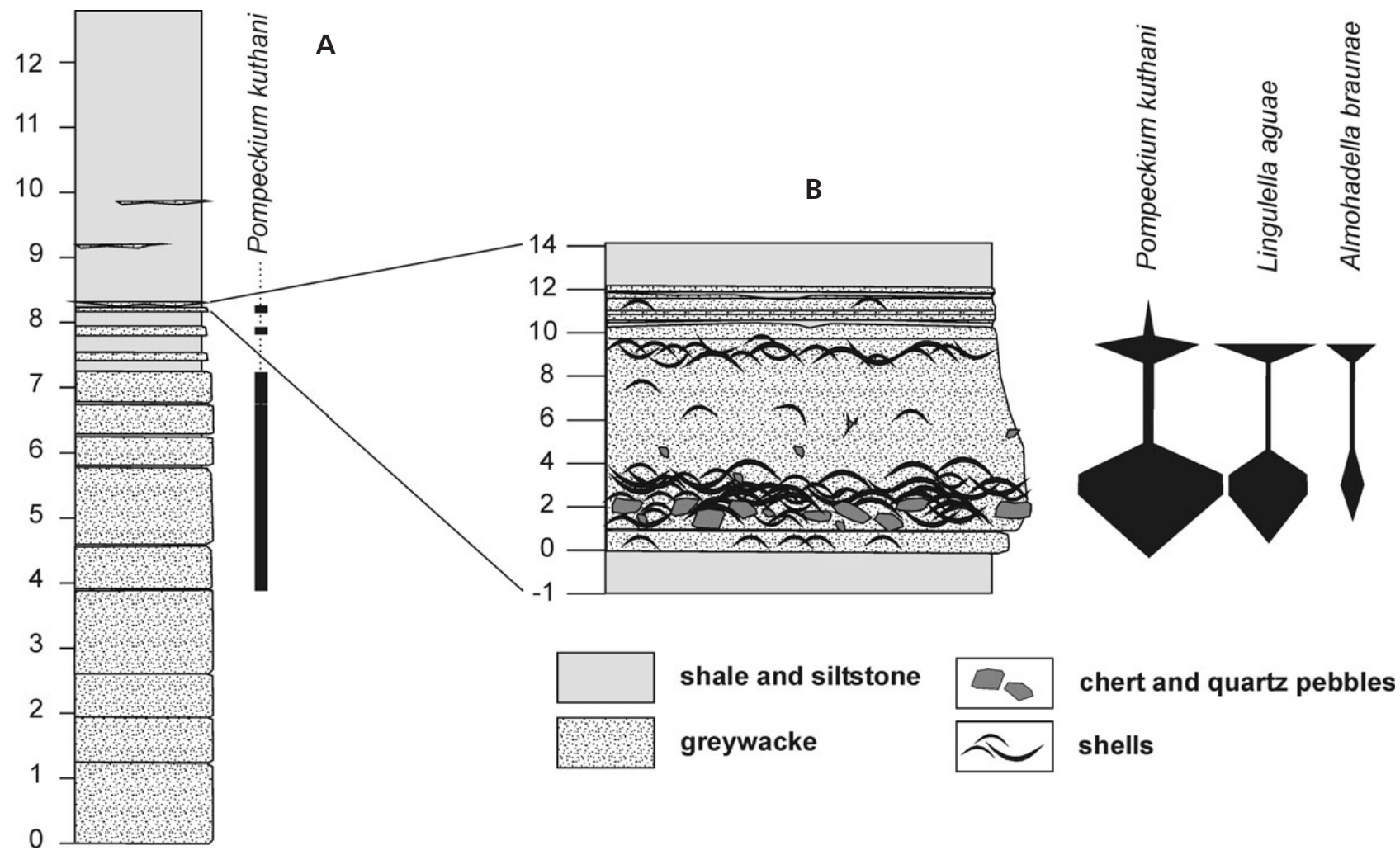

Figure 3. A-generalized stratigraphic sequence of the transition of the Týřovice Greywackes to the Skryje Shales with a fossiliferous bed at Čilá locality with the known range of the orthid Pompeckium kuthani; scale in metres. B - lithology of the fossiliferous bed with marked relative abundance of brachiopods; scale in $\mathrm{cm}$.

cular, at the bottom of a shallow depression or piercing the top of the extended tube. This structure justifies suggesting that the cylindrical pedicle of most acrotretoids was generally short, with a discoidal termination fixed by mucus to a much larger substrate. Although speculative, it is likely that the ceratretid pedicle was distally digitate or enlarged to a lamellose disc and by mucus bonded to a large grain or a few larger grains in the sediment. This adaptation explains why, unlike other acrotretoids, ceratretids have a preference for a substrate of fine sand. The same preference is characteristic of associated semiinfaunal obolids.

The remaining preserved groups associated with the brachiopods belong to suggested mobile detritus feeders and scavengers, represented by trilobites. Rarity of molluscs indicates that grazing or predation was exceptional in the original benthic community. Originally calcareous tubes of unclear affinity could belong to any detritus feeder, but their affinity to a small predatory priapulid can also be suggested.

In summary, the benthic community occupied a shallow shoreface with a predominantly sandy substrate. The shelly fauna consists mainly of low epifaunal suspension feeders (eoorthids, acrotretids) associated with less abundant semi-infaunal suspension feeders (lingulids, cera- tretids). Detritus feeders, represented by heavily sclerotized trilobites were less significant. Grazing browsers (molluscs) were rare. The trophic structure was simple, with a prevalence of essentially immobile low suspension feeders and fewer detritus feeders. The Pompeckium Association sensu Mergl \& Šlehoferová (1990) [or Ptychopariid - mollusc Association sensu Kordule (2006)] represents a typical example of the Cambrian evolutionary fauna with a short and simple food chain.

\section{Palaeogeographic affinity of the fauna}

The shallow water platform carbonate deposits of the late Early and early Middle Cambrian age in Morocco and Spain are rich in the large obolellate Trematobolus or endemic orthids (Saesorthis). Other offshore marly lithofacies from Spain and Sardinia are characterized by kutorginates (Nisusia, Yorkia), moderately diverse acrotretoids, acrotheloids and paterinates (Gil-Cid \& Melou 1986; Mergl 1988; Geyer \& Mergl 1995, 1997; Streng 1999; Linán \& Mergl 2001; Mergl \& Elicki 2004; Wotte \& Mergl 2007). These brachiopod faunas are quite different from contemporaneous associations in Central Bohemia, which are dominated by large lingulids. 




Figure 4. Life strategies of invertebrates in the Pompeckium association. Pompeckium kuthani was an epibenthic suspension feeder, with inhalant water flow higher that $10 \mathrm{~mm}$. Lingulella agaue was a semi-infaunal suspension feeder with inhalant water flow below 10 mm with a shell shallowly buried in the substrate in feeding position. Almohadella braunae and an indeterminable small lingulid were suspension feeders just near the sediment-water interface. Calcareous tubes may indicate a semi-infaunal predatory "worm" (?priapulid similar to Selkirkia). Trilobites (mainly Lobocephalina emmrichi and Germaropyge germari) were scavengers with a mineralised skeleton. Helcionellids and related molluscs were grazers feeding on unpreserved algal or cyanobacterial mats.

The composition of the preserved assemblages, with high abundance of the orthid Pompeckium, ellipsocephalid and ptychopariid trilobites, cup-like molluses and the ceratretid Almohadella in the Týrovice Greywackes is somewhat similar to the assemblage known from the extremely fossiliferous lower part of the Jbel Wawrmast of Morocco (Brèche à Micmacca Member; early Middle Cambrian). Unlike Morocco, the siliciclastic sedimentation in Central Bohemia represented a less favourable space to echinoderms, hyoliths and molluscs. The occasional deposition of fine clay sands made possible the spread of burrowing semi-infaunal lingulids in Bohemia, whereas this group is negligible in the biodetrital limestones of Morocco. The presence of Almohadella both in Morocco and Bohemia indicates weak palaeogeographic barriers between the Perunica terrane and the north Gondwanan periphery. Differences in the mechanical property of marine sediments conditioned by an input of terrigenous material from nearby land were the primary factors controlling the spread of lingulid associations.

\section{Systematic part}

Order Lingulida Waagen, 1885

Superfamily Linguloidea Menke, 1828

Family Obolidae King, 1846

Subfamily Obolinae King, 1846

\section{Genus Lingulella Salter, 1866}

Type species. - Lingula davisii M'Coy, 1851; Ffestiniog Flags Formation, Merioneth Series Upper Cambrian; North Wales.

\section{Lingulella agaue sp. $\mathbf{n}$.}

Figures 5A-K, 6, 7

?1990 Lindinella sp. Mergl \& Šlehoferová, p. 77, pl. 3, figs 5-8.

Holotype. - Dorsal valve (internal and external moulds) illustrated in Fig. 5A, B, stored in the palaeontological collection of the University of West Bohemia in Plzeň (PCZCU 1713a).

Paratype. - Ventral valve (internal and external moulds) illustrated in Fig. 5G, H, stored in the palaeontological collection of the University of West Bohemia in Plzeň (PCZCU 1713b).

Type horizon. - Early Middle Cambrian, Týřovice Greywacke.

Type locality. - Outcrops in a small gorge near Čilá, Skryje-Týřovice area, Central Bohemia.

Material. - 30 dorsal valves and 26 ventral valves, and several fragments preserved as internal and external moulds in weathered calcareous greywacke.

Name. - After Agaué, a nymph of Greek mythology.

Diagnosis. - Moderately (tr.) convex thin-shelled Lingulella with small, narrow (tr.), ventral pseudointerarea with very small outer proparea, deep, gently expanding pedicle groove not raised above valve floor, straight posterolateral margins of ventral valve enclosing $80^{\circ}$ to $85^{\circ}$ apical angle, large, very low anteriorly deeply exca- 
vated dorsal pseudointerarea with median groove having anteriorly weakly convex edge, fine and long dorsal median ridge and an nearly smooth shell exterior with fine growth fila.

Description. - The shell is biconvex, maximum $11 \mathrm{~mm}$ long, with a moderately thick shell.

The dorsal valve is elongate elliptical, with evenly curved posterior and anterior margins, and weakly and unevenly curved sides. The maximum width is situated in the anterior third. The DvL/DvW varies from 1.10 to 1.38 (extremes $1.05 ; 1.41 ; \mathrm{n}=30$ ) (Fig. 6). The valve is evenly convex in transverse profile, and unevenly convex in lateral profile, with the depth maximum in the posterior third. The dorsal pseudointerarea is a clearly defined thin plate, apsacline, weakly raised above the floor, having a deeply undercut anterior edge. The median groove is broadly triangular, with a transverse anterior edge. The propareas are small, narrow (tr.). The dorsal visceral area is weakly defined, with a long anterior projection extending over two-thirds of the valve, terminated by a pair of small anterior lateral muscle scars. The central muscle scars are larger, weakly defined to about midshell length. Transmedian, the outside lateral and middle lateral scars are poorly preserved, and undifferentiated. The shape of the pallial marking is unknown, obviously being weakly impressed. The thin median ridge is long, distinct from the posterior third, separating the central and anterior lateral muscle scars from each another. The interior of the valve bears more or less clearly defined concentric bands of large pits.

The ventral valve is distinctly longer than the dorsal valve, with $\mathrm{VvL} / \mathrm{VvW} 1.20$ to 1.54 (extremes 1.03; 1.56; $\mathrm{n}=26$ ), having an acute beak and an evenly curved anterior margin. The valve outline is broadly subtriangular, with maximum width immediately anterior to midlength. The apical angle is rather uniform in all specimens, from $80^{\circ}$ to $85^{\circ}$, clearly defined by the straight posterolateral margin of the valve. In the transverse profile, the valve is highly convex in the apical part, becoming less convex anteriorly. The maximum depth is posterior to the midlength. The ventral pseudointerarea is clearly defined, raised high above the valve floor, with the anterior border shortly undercut. The pedicle groove is deep, narrowly triangular, with a floor at the same level as the visceral area. Its surface bears transverse growth lines of uneven size. The propareas is defined by clear flexure lines. The inner proparea is shorter, sloping towards the pedicle groove, the outer proparea orthocline, narrower (tr.), and much longer. The surface of the propareas is covered with coarser growth lines arranged at regular intervals, with five to six finer growth lines in between. The visceral area is weakly defined, rhomboidal, in large shells gently raised anteriorly, restricted to 40-50\% of the length of the valve floor. The central muscle scars are large, oblique, with anterior edges enclosing ca $80^{\circ}$ between each another. The vascula lateralia are weakly impressed posterolaterally, leaving only a narrow strip for an attachment of the transmedian and anterolateral muscle scars on the valve floor.

The shell ornament consists of fine growth fila irregularly intercalated by coarser, low growth lamellae. Larval shells and the microornament of postlarval shells are unknown.

Discussion. - Mergl \& Šlehoferová (1990) described under a name Lindinella sp. three shells of a large obolid from the Týřovice Greywackes from Lohovice, a famous locality situated $8 \mathrm{~km} \mathrm{SW}$ from the Čilá site. Specimens referred to Lindinella sp. occurred in the same fauna with associated Lingulella aguae, and it is evident that the original marine environment and stratigraphical age were identical or nearly identical. Lindinella sp. differs in its larger size, with a width of $12 \mathrm{~mm}$, whereas the large specimens of Lingulella aguae do not exceed $9 \mathrm{~mm}$ width. The absence of distinct growth lines distinguishes Linguella agaue from Lindinella sp., but this difference needs further confirmation due to the poor preservation of the latter.

The species Westonia bohemica (Koliha, 1921) and W. fatkai Mergl \& Šlehoferová, 1990, both present in the Jince area, differ from the new species in the anteriorly concave dorsal median groove and coarser ornament. Divaricate ornament is present in the former species. In Lindinella kordulei Mergl \& Šlehoferová, 1990, a similarly anteriorly convex edge of the dorsal median groove is similar to that in Lingulella aguae, but the former differs in its much extended ventral beak, characteristic ornament of regular raised concentric fila, and larger size, with a width exceeding $13 \mathrm{~mm}$.

There are almost no reports of similar large obolids of the early Middle Cambrian age in Europe. Lingulella (?) nathorsti Linnarsson, 1876 is poorly known species from the Middle Cambrian of Scania, Sweden. Similarly shaped

Figure 5. Lingulella aguae sp. n. • A, B - holotype, dorsal valve, latex cast of exterior and internal mould, PCZCU 1713a. $\bullet$ C - dorsal valve, internal mould showing median ridge, PCZCU $1675 . \bullet \mathrm{D}$ - dorsal valve, internal mould showing pseudointerarea, PCZCU 1678 . E - dorsal valve, internal mould showing pseudointerarea, PCZCU 1677. - F - dorsal valve in low-angle light, internal mould showing central muscle scars, PCZCU 1686. $\bullet \mathrm{G}, \mathrm{H}$ - paratype, ventral valve, latex cast of exterior and internal mould, PCZCU $1713 \mathrm{~b}$. $\bullet \mathrm{I}-$ ventral valve, internal mould, PCZCU 1682 . $\bullet$ - ventral valve pseudointerarea, internal mould, PCZCU 1710. $\bullet \mathrm{K}$ - dorsal valve pseudointerarea, internal mould, PCZCU 1685 . All specimens come from a greywacke interbed in the Skryje Shale, locality Čilá near Skryje. Bar equals to $3 \mathrm{~mm}(\mathrm{~A}-\mathrm{I})$ or $1 \mathrm{~mm}(\mathrm{~J}$, K). Gen. et sp. indet. $\bullet \mathrm{L}-$ dorsal valve, internal mould, PCZCU 1688. • M - dorsal valve, internal mould, PCZCU 1711. Specimens come from a greywacke interbed in the Skryje Shale, locality Čilá near Skryje. Bar equals to $2 \mathrm{~mm}$. 
Michal Mergl \& Vratislav Kordule • Middle Cambrian lingulate brachiopods from the Skryje-Týřovice area
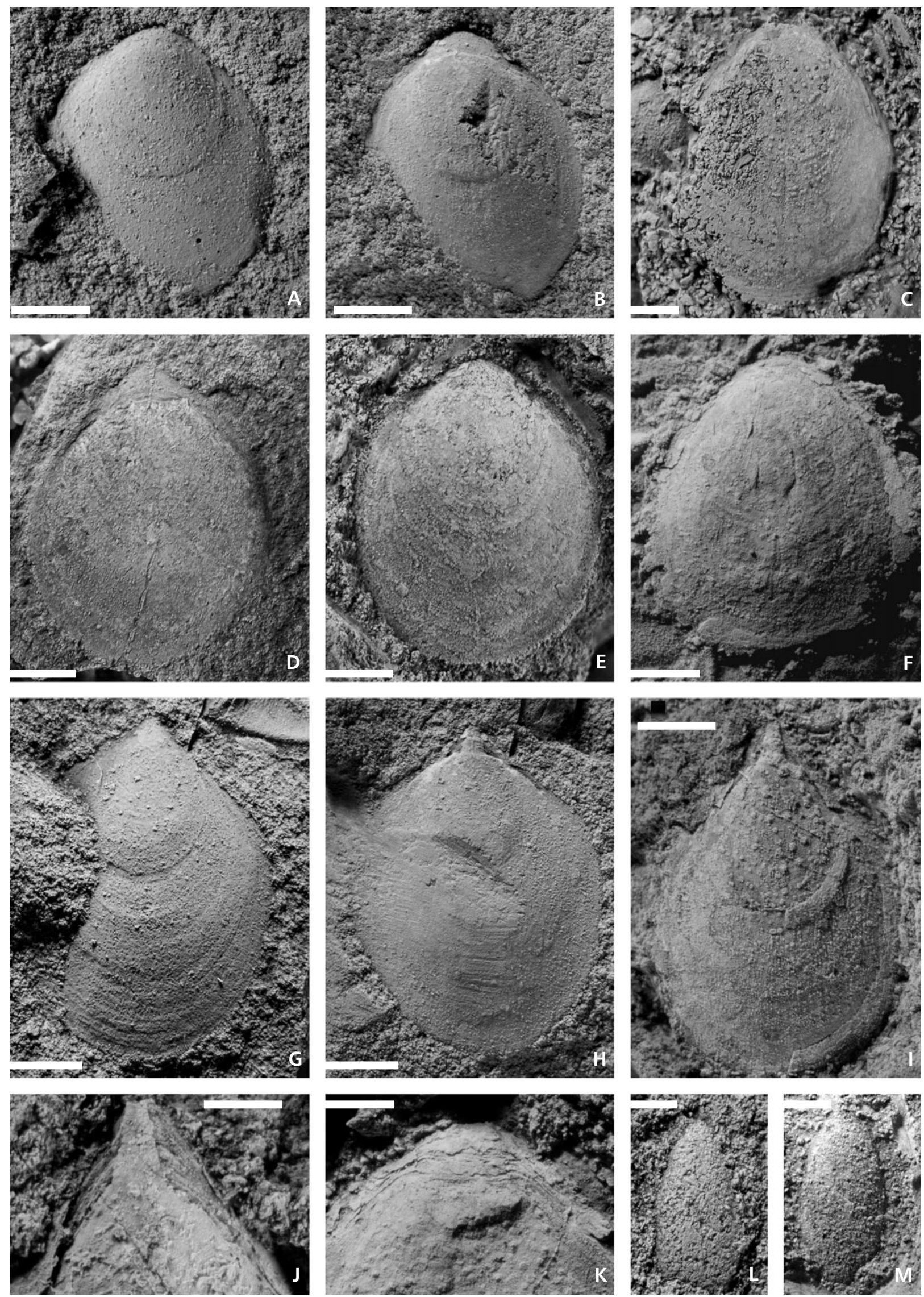


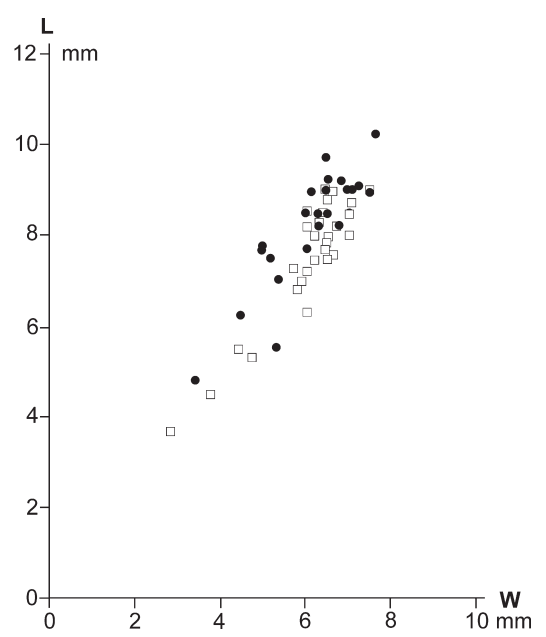

Figure 6. Lingulella aguae sp. n. L/W diagram of ventral (dots) and dorsal (rectangles) valves. $\mathrm{VVn}=26, \mathrm{DVn}=29$.



Figure 7. Lingulella aguae sp. n. Reconstruction of dorsal valve (DV) and ventral (VV) valve interiors. Bar equals to $5 \mathrm{~mm}$. lingulids are known but poorly described from the Upper Cambrian of Spain.

The type species Lingulella davisii M'Coy, 1851 from the Upper Cambrian of North Wales has been revised by Sutton et al. (2000). It differs from the new species by the more subrectangular shell outline, distinctly larger ventral outer propareas, transversally narrower ventral visceral area, anterior concave edge of the dorsal median groove and numerous additional differences in the visceral area arrangement.

The new species is by interareas, weakly impressed muscle scars and pallial markings, smooth interior of shell periphery without intersetal ridges, an elongate oval to subtriangular, moderately convex and almost smooth shell remarkably similar to Leptembolon Mickwitz, 1896. This genus was a characteristic lingulid on temperate periGondwannan and Baltic siliciclastic shelves from the Tremadocian to Dapingian (Popov \& Holmer 1994, Mergl 2002). The clear shell homeomorphology of Lingulella agaue and Leptembolon indicate a similar mode of life and similar environmental requirements for both taxa.

Occurrence. - Type locality only.

Gen. et sp. indet.

Figure 6L, M

Material. - Four dorsal valves.

Remarks. - Four poorly preserved valves indicate the presence of another minute lingulid in the original benthic association. Apart of a distinctly elongate, somewhat parallel-sided outline with a shell length almost double the shell width, all available shells are featureless. In outline and small size, with a length less than $4 \mathrm{~mm}$, the shells are similar to a group of generally poorly understood Cambrian obolids and eoobolids.

Occurrence. - Čilá locality only.

Order Acrotretida Kuhn, 1949

Superfamily Acrotretoidea Schuchert, 1893

Family Acrotretidae Schuchert, 1893

\section{Genus Treptotreta Henderson \& MacKinnon, 1981}

Type species. - Treptotreta jucunda Henderson \& MacKinnon, 1981; Mailchange Limestone, Middle Cambrian; Georgina Basin, Western Queensland, Australia.

\section{Treptotreta? sp.}

Figure 8

Material. - Four dorsal valves.

Description. - The dorsal valve is thin-walled, subcircular, weakly convex, sagittally flattened to form an incipient, shallow sulcus. Length of three valves ranges from 2.25 to $2.85 \mathrm{~mm}$, with DvL/DvW 0.92 to 0.97 . The dorsal pseudointerarea is orthocline, wide, with a broadly triangular median groove. The dorsal median septum is long, extending to almost $86 \%$ of the valve, with a thin base. Median buttresses are absent. The actual height of the septum is unknown. There is an ornament of fine growth fila. The ventral valve is unknown. 
Remarks. - This rare species is known from four dorsal valves and its generic affinity is somewhat obscure. A few Middle Cambrian acrotretids possess distinct, thin, probably blade-like dorsal median septa. Among them, Treptotreta jucunda Henderson \& MacKinnon, 1981 has also large, orthocline pseudointerarea in a subcircular dorsal valve, which is similarly distinct in our specimens. The shells are preliminarily referred to this genus, known from the Middle and Upper Cambrian of Australia, New Zealand, Antarctica, Russia and Kazakhstan (Popov \& Holmer 1994), but additional material is necessary to confirm this attribution. Hadrotreta sp. from the Skryje-Týřovice area, represented by a single dorsal valve (Mergl \& Šlehoferová 1990; pl. 10, figs 17, 18) having a distinct median septum, can belong to the same species. This valve has been found in stratigraphically younger beds with a different trilobite fauna in the Skryje Shales.

Occurrence. - Čilá locality only.

Family Ceratretidae Rowell, 1965

\section{Genus Almohadella Streng, 1999}

Type species. - Almohadella braunae Streng, 1999; Jbel Wawrmast Formation, early Middle Cambrian; Morocco.

\section{Almohadella braunae Streng, 1999 \\ Figures 9, 10}

Material. - 10 dorsal valves and 14 ventral valves, and several fragments preserved as internal and external moulds in weathered calcareous greywacke.

Description. - Shell ventri-biconvex, thick-walled, with rectimarginate commissure, transversally oval to somewhat subrectangular, with L/W 0.73 to 0.85 (extremes 0.69 ; $0.86 ; \mathrm{n}=14), 3.0 \mathrm{~mm}$ wide in the largest collected specimen. Outline, convexity and bilateral symmetry of the shells slightly vary, with maximum width in the anterior third to midlength.

Dorsal valve with evenly rounded anterior and sides, the posterior margin straight. Shell convexity is prominent transversally and sagittally, stepped in the anterior half of the valve due to prominent growth lamellae. Dorsal pseudointerarea short, with a distinct, broadly triangular median groove and short, anacline, narrowly triangular obsolete propareas. Pseudointerarea supported by a broad, strong median buttress, which extends anteriorly into two diverging, sometimes weakly defined ridges. Median ridge absent, but a low elevated pad occupies the central and anterocentral part of the valve. Cardinal muscle scars large,
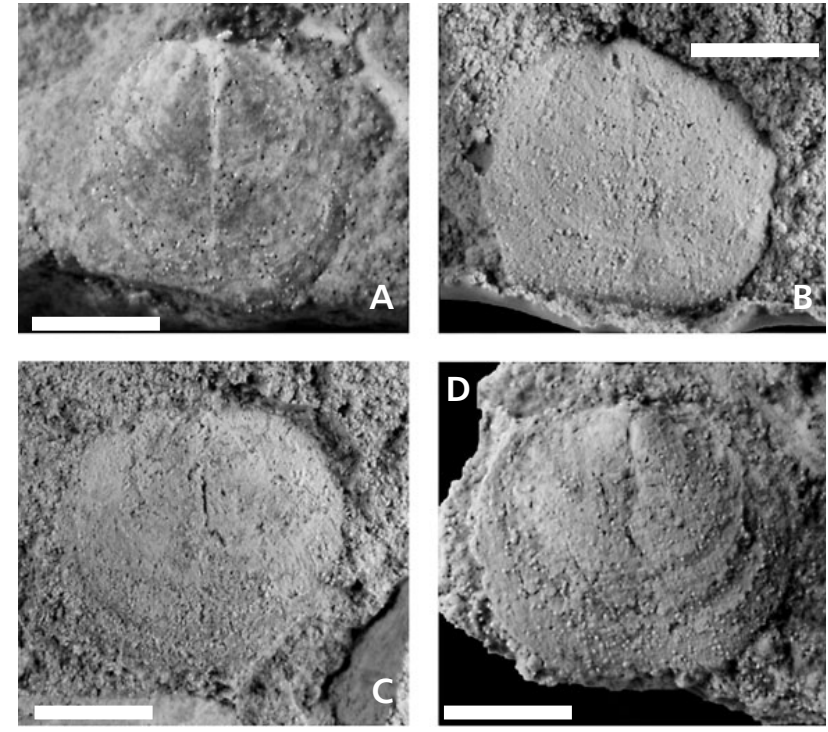

Figure 8. Treptotreta? sp. • A, B - dorsal valve showing length of median septum (uncoated by ammonium chloride) and latex cast of exterior, PCZCU 1689. • C - dorsal valve, internal mould, PCZCU 1691. •D - dorsal valve, internal mould with partly preserved shell, PCZCU 1690. All specimens come from a greywacke bed in the Skryje Shale, locality Čilá near Skryje. Bar equals to $1 \mathrm{~mm}$.

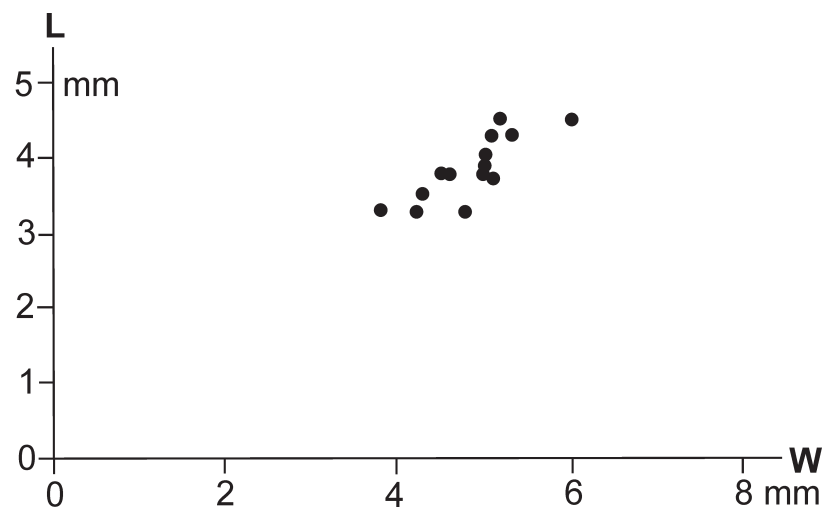

Figure 9. Almohadella braunae Streng, 1999. L/W diagram of ventral valves. $\mathrm{VVn}=14$.

diverging, located in the posterolateral parts of the valve floor. Similarly shaped pair of impressions, probably the site of attachment of the anterior central muscles is located between the central scars and a median buttress. Ventral valve is broadly conical, with W/H 2.89 to 2.04 (extremes $3.07 ; 2.00 ; \mathrm{n}=9$ ).

Apex blunt, directed posteroventrally. Shell highly convex, with evenly rounded top in sagittal profile, the maximum height posterior to midlength. Anterior slope is gently flattened. Lateral slopes gently convex in transverse profile. Ventral pseudointerarea steeply procline, welldefined by a flattening of the posterior slope. Distinct and broad interthrough present, but lateral borders of pseu- 

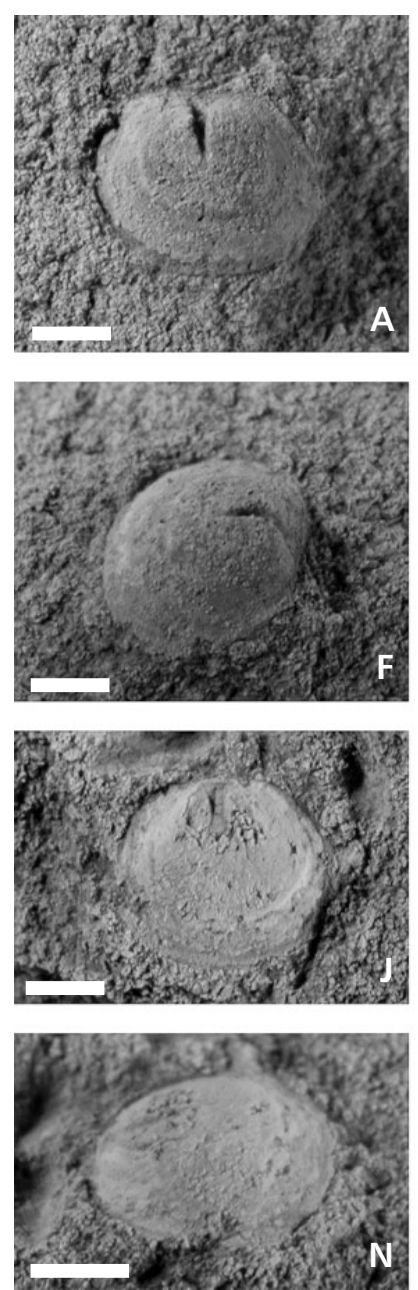
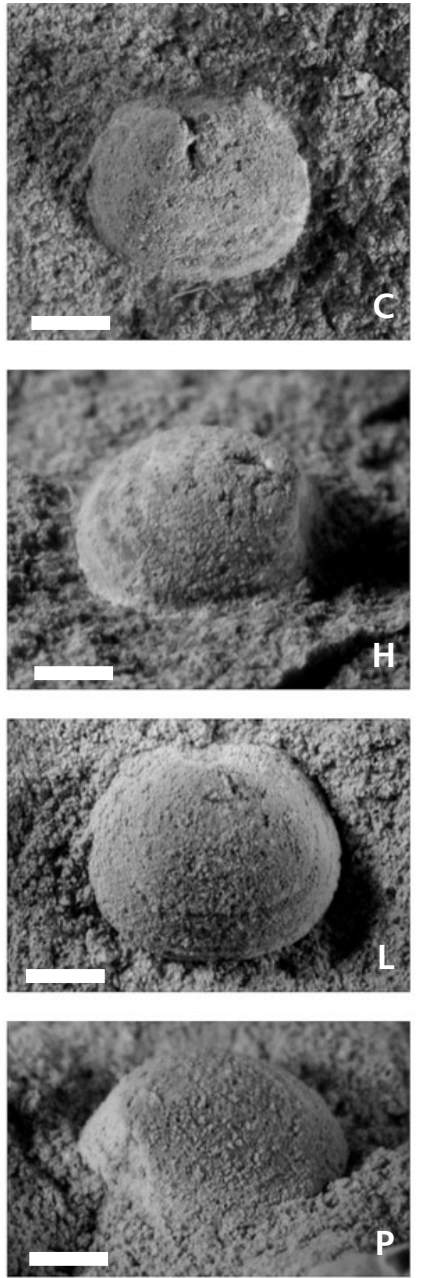


Figure 10. Almohadella braunae Streng, 1999. • A, D-G, I, M, Q - ventral valve showing median septum, internal mould and latex cast of exterior in various views, PCZCU 1692. • B - ventral valve, internal mould, PCZCU 1694. • C, H, L, P - ventral valve, internal mould and latex cast of exterior in various views, PCZCU 1693. - J, K, N, O - dorsal valve, internal mould in and latex cast of exterior in various views, PCZCU 1703. All specimens come from a greywacke bed in the Skryje Shale, locality Čilá near Skryje. Bar equals to $1 \mathrm{~mm}$.

dointerarea less distinct. Pedicle foramen slit-like, opened in the bottom of an elongate sunken depression below the apex. Apical process is a prominent and a high ridge attached to the posterior slope and the valve floor, which extends anteriorly to the midlength of the valve. Sides of the apical process almost parallel, with distinct thickening along the pedicle tube. Pedicle tube circular in section, piercing the apical process and opening internally at the posterior third of valve length. Cardinal muscle scars weakly impressed in the posterolateral slopes of the valve. Minute apical pits located laterally to the pedicle foramen. Vascula lateralia are not discernible.

Shell exterior covered by regular fine growth fila and a few prominent growth lamellae. The lamellae are long but very low. There are three to five lamellae, of which two or three appeared in later growth, being related to increase in shell size.
Remarks. - The Bohemian shells are indistinguishable from the specimens described and figured by Streng (1999) from the early Middle Cambrian of High Atlas, Morocco. The different mode of preservation, with the Bohemian individuals preserved as internal and external moulds, obscures any contingent minor morphological differences. In addition, Streng (1999) noted that the species show highly variable shell morphology, a feature distinct also in the Bohemian specimens. Moroccan specimens occur in early Middle Cambrian (Jbel Wawrmast Formation, Brèche à Micmacca Member, Cephalopyge notabilis to Ornamentaspis frequens Biozones). The similar early Middle Cambrian age for the Bohemian specimens confirms the identity of Moroccan and Bohemian specimens.

Occurrence. - Čilá locality only. 


\section{Acknowledgements}

This study was supported by a grant from the Grant Agency of the Czech Republic (GAČR 205/06/0395). We thank O. Fatka (Charles University, Prague) and L. Popov (National Museum of Wales, Cardiff) for valuable comments.

\section{References}

BARRANDE, J. 1846. Notice préliminaire sur le système silurien et les trilobites de Bohême. Leipzig.

BARRANDE, J. 1852. Système silurien du centre de la Bohême. I ìre partie: Recherches paléontologigues. I. Crustacés. Trilobites. Praha, Paris.

BASSETT, M.G., POPOV, L.E. \& HolMER, L.E. 2002. Brachiopods: Cambrian-Tremadoc precursors to Ordovician radiation events, 13-23. In CRAME, J.A. \& OWEN, A.W. (eds) Palaeobiogeography and Biodiversity Change: the Ordovician and Mesozoic-Cenozoic Radiations. Geological Society, London, Special Publications 194.

Biernat, G. \& TOMCZYKOVA, E. 1968. On the Upper Cambrian Lingulella Salter (Brachiopoda) from the Holy Cross Mountains, Poland. Acta Palaeontologica Polonica 13(2), 159-185.

EMIG, C. 1997. Ecology of inarticulated brachiopod, 473-495. In Williams, A., BRUnTON, C.H.C. \& CARLson, S.J. (eds) Treatise on Invertebrate Paleontology, part H, Brachiopoda, Revised. Volume 1. Geological Society of America \& University of Kansas Press, Boulder \& Lawrence.

EMMRICH, H.F. 1839. De trilobitis. Dissertatio petrefactologica. Berolini.

FATKA, O., Kordule, V. \& SZABAD, M. 2004. Stratigraphical distribution of Cambrian fossils in the Přibram-Jince Basin (Barrandian area, Czech Republic). Senckenbergiana lethaea 84(1/2), 367-381.

GEYER, G. \& MERGL, M. 1995. Mediterranean representatives of the obolellid Trematobolus Matthew (Brachiopoda) and a review of the genus. Paläontologische Zeischrift 69(12), 179-209.

GeYer, G. \& MergL, M. 1997. Protorthacean Brachiopods from the Middle Cambrian of Morocco. Journal of Paleontology 7(5), 791-812.

Gil CID, M.-D. \& MElou, M. 1986. Brachiopodes du Cambrien moyen de Zafra (Province de Badajoz, Espagne). Géologie Méditerranéenne 12-13(3-4), 197-205.

HAVLíčEK, V. 1970. Pompeckium and Jamesella (Orthacea, Brachiopoda) in the Middle Cambrian of Bohemia. Věstník Ústředního ústavu geologického 45(5), 289-290.

HAVLíčEK, V. 1971. Stratigraphy of the Cambrian of Central Bohemia. Sborník geologických věd, Geologie 20, 7-52.

HAVLÍČEK, V. 1989. Climatic changes and development of benthic communities through the Mediterranean Ordovician. Sborník geologických věd, Geologie 44, 79-116.

HENDERSON, R.A. \& MACKINNON, D.I. 1981. New Cambrian inarticulate Brachiopoda from Australia and the age of the Tasman Formation. Alcheringa 5, 289-309.
KING, W. 1846. Remarks on certain genera belonging to the class Palliobranchiata. Annals and Magazine of Natural History (series 1) 18, 26-42.

KoliHA, J. 1921. Ramenonožci z řádu Atremat v českém středním kambriu. Časopis Musea Království českého 95, 29-31.

Kordule, V. 2006. Ptychopariid trilobites in the Middle Cambrian of Central Bohemia (taxonomy, biostratigraphy, synecology). Bulletin of Geosciences 81(4), 277-304. DOI 10.3140/bull.geosci.2006.04.277

KRAFT, J. \& KRAFT, P. 1992. Supinella ovata gen. et sp. n. - the problematic fossil from the Ordovician (Arenig) of Bohemia. C̆asopis pro mineralogii a geologii 37(4), 313-318.

KuHN, O. 1949. Lehrbuch der Paläozoologie. 326 pp. E. Schweizerbart, Stuttgart.

KuKAL, Z. 1971. Sedimentology of Cambrian deposits of the Barrandian area (Central Bohemia). Sborník geologických věd, Geologie 20, 53-100.

LEGRAND, P. 1973. Resultats recents sur le problème de la limite Cambrien-Ordovicien au Sahara algérien septentrional. Bulletin de la Société Histoire Naturelle de l'Afrique du Nord 64(1-2), 159-187.

LEGRAND, P. 1985. Lower Palaeozoic rocks of Algeria, 5-89. In Holland, C.H. Lower Palaeozoic rocks of the world. Vol. 4. Lower Palaeozoic of north-western and west central Africa. John Willey \& Sons, New York.

LinÁN, E. \& MERGL, M. 2001. Lower and Middle Cambrian brachiopods from the Iberian Chains and Sierra Morena (Spain). Revista Española de Paleontologia 16(3), 317-337.

LinNARSSON, J.G.O. 1876. Brachiopoda of the Paradoxides beds of Sweden. Bilhang till Kongliga Svenska VetenskapsAkademiens Handlingar 3, 1-34.

M'Coy, F. 1851. On some new Silurian Mollusca. Annals and Magazine of Natural History, $2^{\text {nd }}$ Series 7, 45-63.

MENKE, C.T. 1828. Synopsis methodica molluscorum generum omnium et specierum earum quae in Museo Menkeano adservantur. 91 pp. G. Uslar, Pyrmonti.

MERGL, M. 1988. Inarticulate brachiopods of early Middle Cambrian age from the High Atlas, Morocco. Věstník Ústředního ústavu geologického 63(5), 291-295.

MERGL, M. 2002. Linguliformean and craniiformean brachiopods of the Ordovician (Třenice to Dobrotivá Formations) of the Barrandian, Bohemia. Acta Musei nationalis Pragae, Series $B$ - historia naturalis 58(1-2), 1-82.

MeRGL, M. \& ELICKI, O. 2004. Cambrian lingulid and acrotretid brachiopods from the Iglesiente area (Campo Pisano Formation, Southwestern Sardinia). Rivista Italiana di Paleontologia e Stratigrafia 110(3), 581-589.

MERGL, M. \& ŠLEHOFEROVÁ, P. 1990. Middle Cambrian inarticulate brachiopods from Central Bohemia. Sborník geologických věd, Paleontologie 31, 9-46.

MickWITZ, A. 1896. Über die Brachiopodengattung Obolus Eichwald. Mémoires de l'Académie Impériale des Sciences de St. Petersbourgh 42, 1-275.

POMPECKJ, J.F. 1896. Die Fauna des Cambriums von Tejřovic und Skrej in Böhmen. Jahrbuch der Geologische Reichsantalts 45, 495-615. 
POPOV, L.E. \& HOLMER, L. 1994. Cambrian-Ordovician lingulate brachiopods from Scandinavia, Kazakhstan, and South Ural Mountains. Fossils and Strata 35, 1-156.

Popov, L.E., KhaZANovitch, K.K., BOROVKO, N.G., SeRGEEVA, S.P. \& SOBOLEVSKAYA, R.F. 1989. Opornye razrezy i stratigrafiia kembro-ordovikskoi fosforitonosnoi obolovoi tolshchi na severno-zapade Russkoi platformy [The key sections and stratigraphy of the phosphate-bearing Obolus Beds on the north-east of Russian Platform]. 222 pp. AN SSSR, Mezhvedomstvennyi stratigraficheskii komitet SSSR, Trudy 18. Nauka, Leningrad (in Russian).

RŮŽıČKA, R. 1939. Trilobiti nejstarší české kambrické fauny od Týřovic z Kamenné hůrky. Rozpravy I. tř́dy České akademie $49,1-12$.

Rowell, A.J. 1965. Inarticulata, H260-H297. In MoORE, R.C. (ed.) Treatise on Invertebrate Paleontology, part H, Brachiopoda, Vol. 1. Geological Society of America and University of Kansas Press, Boulder.

SALTER, J.W. 1866. On the fossils of North Wales, 239-381. In RAMSAY, A.C. The geology of North Wales. Memoirs of the Geological Survey of Great Britain and of the Museum of Practical Geology 3.

SCHUCHERT, C. 1893. A classification of the Brachiopoda. American Geologist 11, 1341-167.
STRENG, M. 1999. Early Middle Cambrian representatives of the superfamily Acrotretoidea (Brachiopoda) from Morocco. Zeitschrift der deutschen geologischen Gesselschaft 150(1), 27-87.

SutTon, M.D., BAssetT, M.G. \& Cherns, L. 2000. The type species of Lingulella (Cambrian Brachiopoda). Journal of Paleontology 74(3), 426-438. DOI 10.1666/0022-3360(2000)074<0426:TTSOLC >2.0.CO;2

ŠNAJDR, M. 1958. Trilobiti českého středního kambria. Rozpravy Ústředního ústavu geologického 24, 1-280.

ŠNAJDR, M. 1975. Konicekion nov. gen. from the Middle Cambrian of Bohemia. Věstník Ústředního ústavu geologického 50(3), 153-156.

USHATINSKAYA, G.T. 1996. Brachiopod paleozoogeography through the Cambrian, 275-280. In COPPER, P. \& JISUO, J. Brachiopods. Proceedings of the Third International Brachiopod Congress, Sudbury, Ontario, Canada, 2.-5. September 1995. A.A. Balkema, Rotterdam.

WAAGEN, W. 1885. Salt Range fossils, I. Productus-Limestone fossils, Brachiopoda. Memoirs of the Geological Survey of India, Palaeontologia Indica (series 13) 4(5), 729-770.

WotTe, T. \& MergL, M. 2007. Brachiopods from the LowerMiddle Cambrian Láncara Formation of the Cantabrian Mountains, Northwest Spain. Memoirs of the Association of Australian Palaeontologists 33, 101-122. 